\title{
The Influence of Transformational Leadership Behaviours on Organizational Commitment in Omani Governmental Organizations
}

\author{
Salim Musabah Bakhit Al Zefeiti ${ }^{1,2}$ \\ ${ }^{1}$ Universiti Teknologi Malaysia, Malaysia \\ ${ }^{2}$ Deputy Director General of Expenditure Office, Royal Court Affairs, Sultante of Oman \\ Correspondence: Salim Musabah Bakhit Al Zefeiti, Deputy Director General of Expenditure Office, Royal Court \\ Affairs, Sultante of Oman. E-mail: albatinah@hotmail.com
}

Received: January 16, 2017

Accepted: February 20, 2017

Online Published: March 26, 2017

doi:10.5539/ijbm.v12n4p111

URL: https://doi.org/10.5539/ijbm.v12n4p111

\begin{abstract}
Public organizations all over the world have to confront renewed challenges and obstacles to meet citizens' needs. Indeed, Omani organizations are required to have leadership behaviours that clearly encourage and foster subordinates' performance by enhancing employees' commitment. The aim of this paper is to explore the influence of transformational leadership on organizational commitment in Omani public organizations. The quantitative data was collected through survey instrument. The current research utilized AMOS to investigate the measurement model and test the proposed hypothesised relationship between the constructs. The population for this study consisted of Omani public organization that apply civil service law. The sample consists of 336 middle managers in Omani public organizations. The results found that transformational leadership play a pivotal role in enhancing organizational commitment. Specifically, core transformational leadership has a direct impact on all organizational commitment dimensions (affective, normative, and continuance). Whereas, providing individualized support, intellectual stimulation, and setting high performance expectation have a direct impact on both continuance and normative commitment.
\end{abstract}

Keyword: Affective commitment, continuance commitment, normative commitment, Oman organizational commitment, public organization, transformational leadership behaviors

\section{Introduction}

Leadership is one of the complex areas that have been known in the past and recently that influences various aspects in organization's daily business. It is arguably believed that, a group of people work together within any organization necessarily requires a leader having the ability to lead and motivate them to achieve their targets. Leadership is the process of convincing subordinate or follower to work together and make their best to achieve the desired results, as well as, directing them to move in the right direction and obtain their commitment and motivation to complete desirable goals in certain time. Leadership is the process of directing the behaviour of followers to achieve the organization common goals (Burns, 1978).

In the past several decades, management experts have undergone a revolution in how they define leadership and what their attitudes are toward it. They have gone from a very classical autocratic style to a very creative, participative style. However, there is no one best style that can be used for all situations. Thus, different behaviours are needed for different situations and each leader needs to know when to exhibit a particular behaviour. The various leadership behaviours differ in terms of the processes by which leaders influence followers. It is the ethical implications of these differences in process that appear to be considered by researchers when investigating ethical leadership (Aronson, 2001).

Public organizations all over the world have to confront renewed challenges and obstacles to meet citizens' needs (Nusair, Ababneh, \& Bae, 2012). Indeed, the last few years Omani government has faced high expectation from Omani citizen to provide better services. For that reason, Ministry of Civil Service conducted a symposium to develop and enhance Omani governmental organizations' performance (Ministry of Civil Service, 2012). Omani public organizations have no choice but to perform or bear the consequence of failure. They are compelled to overcome the given environmental constraints and to get rid of their traditional management practices. Consequently, they are obliged to become flatter, flexible, and diverse to survive and advance their credibility. 
However, in order to overcome these challenges, Omani organizations are required to have leadership behaviours that clearly encourage and foster subordinates' performance by enhancing employees' commitment.

Literature review shows that there are two forms of research on organizational commitment; antecedents and outcomes of organizational commitment (Marique, Stinglhamber, Desmette, Caesens, \& De Zanet, 2012). Researchers argue that there are many factors impact organizational commitment have been acknowledged which consist of personal aspects, job aspects and organizational aspects (Mowday, Steers, \& Porter, 1979). However, there is a lack of study conducted to determine the factors impacting the Omani public employees' organizational commitment. Researchers argued that employees who are psychologically attached to an organization are more satisfied and, in turn, more productive (Hunter \& Thatcher, 2007). Therefore, organization nowadays, strive to enhance employees' organizational commitment (Morrow, 2011).

Transformational leadership is a process that changes people by affecting emotions, values, ethics, standards, and long-term goals. Certainly, transformational leadership involves an unusual form of influence on the leader's part that moves followers to accomplish more than what is usually expected from them (Northouse, 2010). Employees under Supervision of transformational leaders are expected to have a strong perceptions of being treated fairly and, in return, will work harder to achieve organizational goals and develop commitment towards their organizations (Wang, Ma, \& Zhang, 2014).

\subsection{Problem Statement}

Omani public organizations are expected to take a leading role in providing different kind of best services to the community such as, health services, educational services, transportation and communications, and housing services. But if they want to be more successful, they require to response very quick to the fast movement in business domain by clearly encourage and foster subordinates' organizational commitment as well as practicing appropriate leadership behaviors that could enhance their employees' performance. Definitely, this sector needs proficient leaders who can accomplish all the goals and objectives of both employees and organizations. Organizations that are short of capital may resort to borrowing money. However an organization with ineffective leadership has little chance for survival (Darwish A. Yousef, 1998).

Therefore, the relationship between transformational leadership and organizational commitment has attracted considerable interest from both academics and practitioners. Much of the interest on these variables is based on the results of the previous studies which have asserted that these concepts may have an impact on the organizations goals and objectives (Z. Khan, Khan, \& Shahzad, 2013; Darwish A Yousef, 2000). Yet, there is a lack of research investigating leadership within public sector organizations (AlKindy, Shah, \& Jusoh, 2016) in Arabian Gulf Countries in general (Hajee \& Al Hashemi, 2012), and in the Sultanate of Oman in particular (AlKindy et al., 2016; Common, 2011). Moreover, there is a dearth of literature on the possible impact of transformational leadership on organizational commitment in the non-profit setting (Freeborough, 2012). Furthermore, there is limited studies focusing on the influence of transformational leadership on organizational commitment dimensions (Meyer, Stanley, Herscovitch, \& Topolnytsky, 2002; So, 2009).

This study, therefore, is unique as it will help to address this issue in an effort to improve the understanding of the influence of transformational leadership on employees' organizational commitment in Arabian Gulf Countries in general and in Omani setting in particular.

\subsection{Research Objectives}

The objective of this paper aims to examine the impact of transformational leadership dimensions on employees' organizational commitment (affective, normative, continuous) in Omani public organizations. Based on the research objective stated, the following research question was addressed:

Q1. Do transformational leadership dimensions impact Omani employees' organizational commitment (affective, normative, continuous).

\section{Literature Review}

\subsection{Transformational Leadership}

Transformational leadership was originally developed by James MacGregor Burns in 1978. Burns introduced this concept in his descriptive research on political leaders (Burns, 1978). Transformational leadership encourage employees to perform more than what they originally thought possible (Sarros, Gray, \& Densten, 2002), by motivating and inspiring their subordinates' value and self-esteem to go beyond egoistic interests (Felfe, Tartler, \& Liepmann, 2004: p.266). The primary goal of this leadership is to transform followers toward a relationship that shift the dependent responsibility for into a relationship that is interdependent, and people are responsible to 
each other. A transformational leader's bottom line goal is to bring followers up to the level of confidentially accomplishing organizational tasks without direct leader intervention (Einstein \& Humphreys, 2001). According to Podsakoff, MacKenzie, Moorman, and Fetter (1990) the dimensions of Transformational leadership are as following:

a. Core transformational leadership that consists; (1) Identifying and Articulating a Vision (IAV): This behaviour is aimed at the identifying and communicating a clear vision of the future to their subordinates. (2) Providing an Appropriate Model (PAM): this behaviour is aimed at providing an example for subordinates to follow that are consistent with shared values. (3) Fostering the Acceptance of Group Goals (FAGG): Leader fosters the acceptance of group goals by encouraging self-sacrifice for the sake of the group.

b. Providing Individualized Support (PIS): Leader respects subordinates' needs, makes sure that the assigned work is in accordance with subordinates needs and abilities.

c. Intellectual stimulation (IS): leader challenges subordinates to look at their work in different ways, encourages them to be creative, and learn new opportunities.

d. Setting High Performance Expectation; Leader seeks high quality achievement and insists on only the best performance

Academics and researchers, in the last three decades, have received increasing attention about the new paradigm called transformational leadership style (Shurbagi, 2014) where the interest of this study lays. Transformational leadership, particularly, aims to change and transform employees (Northouse, 2012). Researchers argue that transformational leadership has some degree of universality (B. M. Bass \& Avolio, 1994; Podsakoff et al., 1990). However, Randeree and Chaudhry (2012) assert that the universality of the transformational leadership may be limited to cultural differences. Undeniably, transformational leadership effectiveness is affected by the organizations and cultures in which it appears. In light of that, researchers stress that the impact of leadership on organizational outcomes should be scrutinized in different culture (Kuchinke, 1999; Pieterse, Van Knippenberg, Schippers, \& Stam, 2010). Transformational leadership is needed because the old theories of leadership, operating through the power of performance-reward linkage has become less relevant (Srivastava, 2003). It is argued that, employees working under leaders who exhibit transformational leadership are expected to report higher levels of organizational commitment (Dunn, Dastoor, \& Sims, 2012). Moreover, Bernard M Bass (1985) suggests that transformational leadership behaviours might contribute to employees' confidence in both usual and unusual ways to build up their organizational commitment in a much stronger way. Transformational leaders have a considerable influence on enhancement of employees' performance by increasing their organizational commitment (Z. Khan et al., 2013). Thus, the study wishes to test transformational leadership theory and its impact on organizational commitment at Omani public service sector.

\subsection{Organizational Commitment}

It is believed that human resources are critical for organizational effectiveness since it plays a great influence on sustaining organizational competitive advantages through teams of committed employees. Practitioners and researchers have paid a considerable effort to study organizational commitment due to its impact on various organizational outcomes such as work performance (Dirani, 2009). Indeed, committed employee is a better predictor for high performance. Lowe (2000) recommended extra research on employee commitment due to its importance to enhance public service motivation. Similarly, Wang et al. (2014) pointed out that how to motivate employees to work hard and to exhibit a high level of commitment to the organization is a subject worthy of extra investigation. The interest in organizational commitment has increased in most types of organizations whether they are private or public, civilian or military, profitable or non-profitable. In the literature, organizational commitment has been defined differently and thus they are many definition for organizational commitment. However, most of organizational commitment share the view that commitment is a psychological state that characterizes employees' relationship with their organization (Meyer \& Allen, 1997). Whereas, Gunlu et al., (2010) defined organizational commitment as the relative strength of a person's identification with and involvement in a specific organization. Committed employees are more likely to remain with the organization (Meyer et al., 1989) and display extra role behavior (Mathieu \& Zajac, 1990).

Meyer and Allen (1997) defined organizational commitment as a strong belief in and acceptance of an organisation's goals and values; a willingness to exert considerable effort on behalf of an organisation and a strong desire to remain with the organisation. Researchers in their review of the organisational commitment literature identified three general themes in the definition of commitment (Meyer \& Allen, 1991; Shaw, Delery, \& Abdulla, 2003). 


\section{(a) Affective Commitment}

Meyer and Allen (1991) describe affective commitment as the desire to be emotionally involved in a particular organisation. They believe that it involves employees' long term feelings towards their jobs. Employees with a strong affective commitment continue with their organisation because they want to do so.

\section{(b) Continuance Commitment}

It has been found that, continuance commitment is described as perceived costs associated with leaving the organisation. This indicates that when employees bear higher cost of leaving organisation, they are more committed to their organizations not because they want to, but because they have to (Meyer \& Allen, 1991)

\section{(c) Normative Commitment}

Scholars in the field of management describe normative commitment as the obligation to remain in a particular organisation (Meyer \& Allen, 1991; Bryant et al., 2007; Lumley et al., 2011). In this type of commitment employees remain with their organisation because they feel that they should to do so for moral reasons, not because they want or need to (Meyer \& Allen, 1991)

\subsection{The Relationship between Transformational Leadership and Organizational Commitment}

Organizational commitment has emerged as a promising area of research in recent time (D. Adebayo, 2006; Jafri \& Lhamo, 2013) because it plays an important role in employees behaviour (Berberoglu \& Secim, 2015). Employees with high organizational commitment tend to perceive their leaders as more trustworthy than employees who have low organizational commitment (Caldwell, 2011).

Shamir, House, and Arthur (1993) suggest that transformational leadership role in enhancing employees' organizational commitment can be viewed as a motivational process, since transformational leaders encourage employees to exert extra effort and to think creatively about complex problems, provide positive feedback, and build commitment to the organization's strategies, mission, and objectives (Piccolo \& Colquitt, 2006; Yukl, 1998).

Transformational leaders build a strategic vision and communicate that vision to create commitment toward the vision (B. M. Bass \& Avolio, 1994). Moreover, Appelbaum and Goransson (1997) building a shared vision is very important for gathering a group of people to work together to raise a commitment to a common future they strives to generate. a considerable research has been conducted over the past two decades to determine how employees' commitment to an organisation develops (Meyer \& Allen, 1997). It is argued that transformational leadership has the ability to inspire and motive subordinates to achieve organisational goals and objectives (Burns, 1978). Hence, transformational leadership is used in this research as it is best suited to support and foster a work environment that focuses on organizational issues of commitment (Baek-Kyoo, Yoon, \& Jeung, 2012; Freeborough, 2012; Podsakoff, MacKenzie, \& Bommer, 1996).

Indeed, the relationship between transformational leadership and organizational commitment has received a great deal of attention in past research. The findings, however, are mixed. Mancini (2008) argues that there is a negative relationship between continuous commitment and transformational leadership factors with the strongest negative relationship being with the inspirational motivation factor. Tuna, Ghazzawi, Akbas Tuna, and Catir (2011) suggest that the charisma sub-dimension has a positive association with affective commitment and normative commitment. However, it reveals a poor association with continuance commitment. Moreover, the intellectual stimulation dimension revealed a poor association with affective and normative commitment but did not find any link with continuance commitment. Finally, they illustrates a positive association between individual consideration sub-dimension and affective and continuance commitment but poor association with normative commitment.

On the other hand, many of previous studies have supported a positive relationship between transformational leadership and organizational commitment (Dimaculangan \& Aguiling, 2012; Z. Khan et al., 2013; Yang, 2012), which are posited to increase several of positive business outcomes (Walumbwa \& Lawler, 2003; Zhu, Avolio, \& Walumbwa, 2009). Researchers have postulated that transformational leadership has a positive association with organizational commitment in different organizational contexts and cultures (Avolio, Zhu, Koh, \& Bhatia, 2004; Bono \& Judge, 2003; Walumbwa \& Lawler, 2003).

Therefore, based on the results in the literature, as shown in Figure 1, it would be meaningful to examine the influence of transformational leadership behaviours on employees' organisational commitment, which led to the formulation of the research hypotheses as below:

H1: There is a significant impact of core transformational leadership on organizational affective commitment. 
$\mathrm{H} 2$ : There is a significant impact of providing individualized support on organizational affective commitment.

H3: There is a significant impact of intellectual stimulations on organizational affective commitment.

H4: There is a significant impact of setting high performance expectation on organizational affective commitment.

H5: There is a significant impact of core transformational leadership on organizational continuance commitment.

H6: There is a significant impact of providing individualized support on organizational continuance commitment.

H7: There is a significant impact of intellectual stimulations on organizational continuance commitment.

H8: There is a significant impact of setting high performance expectation on organizational continuance commitment.

H9: There is a significant impact of core transformational leadership on organizational normative commitment.

H10: There is a significant impact of providing individualized support on organizational normative commitment.

H11: There is a significant impact of intellectual stimulations on organizational normative commitment.

H12: There is a significant impact of setting high performance expectation on organizational normative commitment.

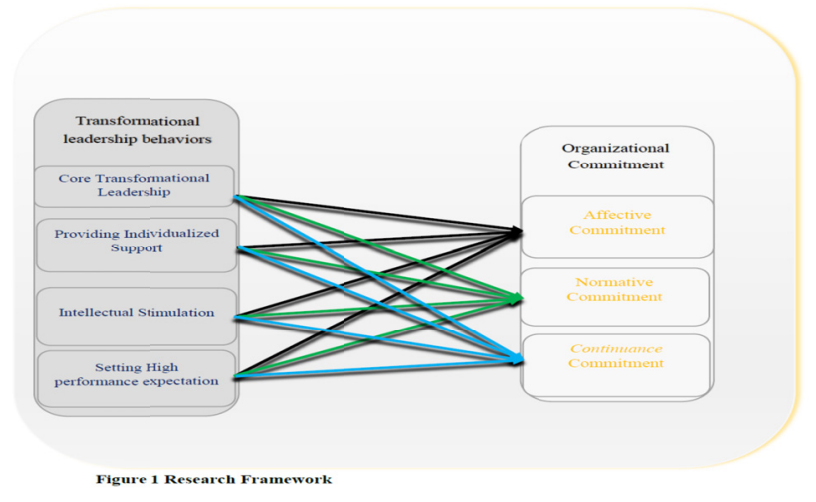

Figure 1. Research Framework

\section{Research Methodology}

\subsection{Sample and data Collection}

The research used a quantitative data was collected through survey instrument, using five-point Likert scales ranging from 1-strongly disagree to 5-strongly agree. The population for this study consisted of Omani public organizations that apply Civil Service Law. The sample consists of 335 of Middle managers working in Omani public organizations. The stratified sample sampling was used in this study and the sample size has been chosen according to the population of Omani public civil services organizations that applying Civil Service law and the percentage of the middle managers in each organizations then the sample was selected randomly.

\subsection{Transformational Leadership Questionnaire}

This research evaluates transformational leadership behaviours using items adapted from measures produced by Podsakoff et al. (1990). Transformational leadership inventory (TLI) that were originally developed by Podsakoff et al. (1990), and afterward further tested (e.g., (Podsakoff et al., 1996), was found to have good psychometric properties with regard to reliability and validity of the scales and argued to be more widely used (Schriesheim, Alonso, \& Neider, 2008).

\subsection{Organizational Commitment Questionnaire}

This study required an instrument which focused on how employees' commitment to their organization was related to the subordinates' perception of their supervision transformational leadership. In this regard, Meyer and Allen (1991), and Meyer, Allen, and Smith (1993) commitment scale was used to measure organizational commitment. This instrument is composed of different types of organizational commitment; (a) affective commitment, (b) normative commitment and, (c) continuance commitment. Researchers investigated the construct validity and internal reliability of the OCQ and found that measures exhibited both convergent and 
discriminant validity (Karim \& Noor, 2006).

\section{Result}

The current research utilized AMOS to investigate the measurement model and test the proposed hypothesised relationship between the constructs. Thus, multivariate assumptions such as; normality, multicollinearity and outliers were diagnosed, prior to the analyses. The results revealed that the data met all requirements so that the multivariate requirement was not a serious concern in this study. Confirmatory factor analysis (CFA) was used to examine the measurement model construct validity and reliability. Measurement model had been tested on multiple stages. At the first stage, all latent constructs were correlated to test the measurement model fitness of all constructs. In SEM model fitness can be tested on the basis of absolute fit indices, incremental fit indices and parsimony fit indices (Hooper, Coughlan, \& Mullen, 2008). The first test indicated that, the default model required some adjustments, in order to achieve the required model fitness. First step was to remove those items, showing factor loading less than 0.50 (Hair, Black, Babin, \& Anderson, 2010). Initial results signalled a weak model fit and item loadings of the constructs. The results of the initial factor loadings of items IVA6, AC6, NC1, and $\mathrm{NC2}$, were removed from the further analysis due to low value of factor loading, rest of the items were retained. The values for goodness of fit was $\chi 2=1070.159, \mathrm{df}=834, \mathrm{CMIN} / \mathrm{DF}=1.283, \mathrm{GFI}=0.876, \mathrm{TLI}=0.976$, $\mathrm{CFI}=0.978, \mathrm{RMR}=0.034$ and $\mathrm{RMSEA}=0.029$.

The last step for achieving model fitness was to correlate error terms of the items having modification indices above than 40. Cronbach's alpha and variance extracted scores confirm internal consistency (Cronbach's alpha $>.70$ ) and convergent validity shows that all values of factor loading were above than 0.50 . Discriminate validity is assured because results indicate that all the constructs have adequate discriminant validity, as the square root of average variance extracted is greater than inter-construct correlation of each variable and also the values of inter construct correlation are less than .85. Figure 2 illustrates the measurement model.

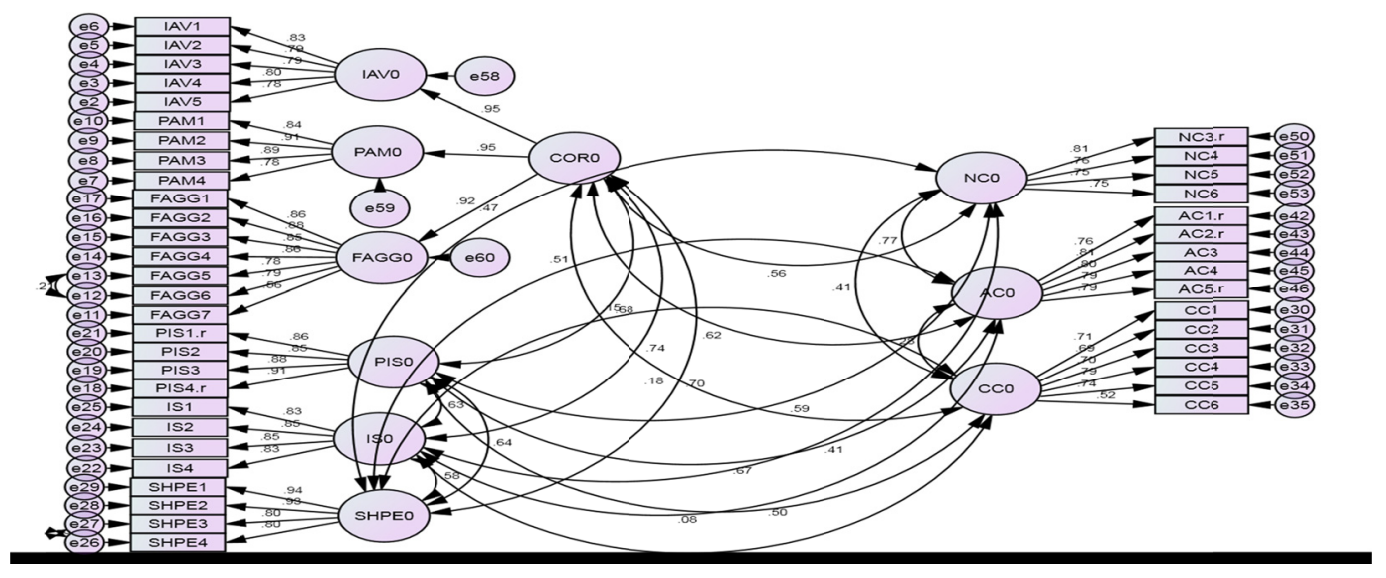

Figure 2. Measurement model

This study hypothesized that, four dimensions of transformational leadership behaviours (core transformational leadership, providing individualized supports, intellectual stimulation, and setting high performance expectations) have a significant effect on organizational commitment (affective commitment, continuance commitment, and normative commitment) (H1 and H12). Figure 3 illustrates results of the path model.

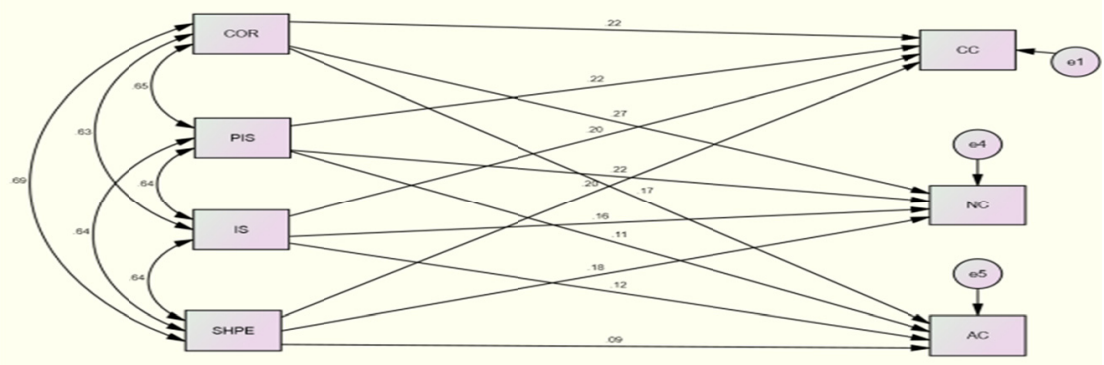

Figure 3. Transformational leadership- organizational commitment 
The researcher proposed the hypothesis H1: Core transformational leadership (core) has a direct impact on affective commitment (AC). Results as shown in table 1 indicated that the path coefficient value is 0.201 ; critical ratio is 2.301 and $\mathrm{p}$ value 0.021 . This indicates the significance of the direct impact of Core on AC. The researcher proposed the hypothesis H2: Providing individualized support (PIS) has a direct impact on affective commitment $(A C)$. Results as shown in table 1 indicated that the path coefficient value is 0.125 ; critical ratio is 1.491 and $\mathrm{p}$ value 0.136 . This indicates there is insignificance direct impact of PIS on AC. The researcher proposed the hypothesis H3: Intellectual stimulations (IS) has a direct impact on affective commitment(AC). Results as shown in table 1 indicated that the path coefficient value is 0.148 ; critical ratio is 1.729 and $\mathrm{p}$ value 0.084. This indicates there is insignificance direct impact of IS on AC. The researcher proposed the hypothesis H4: Setting high performance expectations (SHPE) has a direct impact on affective commitment(AC). Results as shown in table 1 indicated that the path coefficient value is 0.106 ; critical ratio is 1.228 and $p$ value 0.219 . This indicates there is insignificance direct impact of SHPE on AC.

H5: Core transformational leadership (core) has a direct impact on Continuance commitment(CC). Results as shown in table 1 indicated that the path coefficient value is 0.231 ; critical ratio is 3.865 and $\mathrm{p}$ value 0.000 . This indicates the significance of the direct impact of Core on CC. H6: Providing individualized support (PIS) has a direct impact on Continuance commitment $(C C)$. Results as shown in table 1 indicated that the path coefficient value is 0.224 ; critical ratio is 3.897 and $\mathrm{p}$ value 0.000 . This indicates the significance of the direct impact of PIS on CC. H7: Intellectual stimulations (IS) has a direct impact on Continuance commitment(CC). Results as shown in table 1 indicated that the path coefficient value is 0.207 ; critical ratio is 3.549 and $p$ value 0.000 . This indicates the significance of the direct impact of IS on CC. H8: Setting high performance expectations (SHPE) has a direct impact on Continuance commitment $(C C)$. Results as shown in table 1 indicated that the path coefficient value is 0.202 ; critical ratio is 3.410 and $\mathrm{p}$ value 0.000 . This indicates the significance of the direct impact of SHPE on CC.

H9: Core transformational leadership (core) has a direct impact on Continuance commitment(CC). Results as shown in table 1 indicated that the path coefficient value is 0.262 ; critical ratio is 4.714 and $p$ value 0.000 . This indicates the significance of the direct impact of Core on NC. H10: Providing individualized support (PIS) has a direct impact on normative commitment $(N C)$. Results as shown in table 1 indicated that the path coefficient value is 0.212 ; critical ratio is 3.971 and $\mathrm{p}$ value 0.000 . This indicates the significance of the direct impact of PIS on NC. H11: Intellectual stimulations (IS) has a direct impact on normative commitment(NC). Results as shown in table 1 indicated that the path coefficient value is 0.159 ; critical ratio is 2.922 and $\mathrm{p}$ value 0.003 . This indicates the significance of the direct impact of IS on NC. H12: Setting high performance expectations (SHPE) has a direct impact on normative commitment $(N C)$. Results as shown in table 1 indicated that the path coefficient value is 0.165 ; critical ratio is 3.005 and $p$ value 0.003 . This indicates the significance of the direct impact of SHPE on NC.

\begin{tabular}{|c|c|c|c|c|c|c|c|c|}
\hline \multicolumn{4}{|c|}{ Hypothesized path } & \multirow{2}{*}{$\begin{array}{l}\text { B } \\
.201\end{array}$} & \multirow{2}{*}{$\begin{array}{l}\text { S.E. } \\
.087\end{array}$} & \multirow{2}{*}{$\begin{array}{l}\text { C.R } \\
2.304\end{array}$} & \multirow{2}{*}{$\begin{array}{l}\mathrm{P} \\
.021\end{array}$} & \multirow{2}{*}{$\begin{array}{c}\text { Supported } \\
\text { Yes }\end{array}$} \\
\hline H1 & Core & $\rightarrow$ & $A C$ & & & & & \\
\hline H2 & PIS & $\rightarrow$ & $A C$ & .125 & .084 & 1.491 & .136 & No \\
\hline $\mathbf{H 3}$ & IS & $\rightarrow$ & $A C$ & .148 & .085 & 1.729 & .084 & No \\
\hline H4 & SHPE & $\rightarrow$ & $A C$ & 106 & 086 & 1.228 & 219 & No \\
\hline H5 & Core & $\rightarrow$ & $\mathrm{CC}$ & .231 & .060 & 3.865 & .000 & Yes \\
\hline H6 & PIS & $\rightarrow$ & $\mathrm{CC}$ & .224 & .057 & 3.897 & .000 & Yes \\
\hline H7 & IS & $\rightarrow$ & $\mathrm{CC}$ & .207 & .058 & 3.549 & .000 & Yes \\
\hline HS & SHPE & $\rightarrow$ & $\mathrm{CC}$ & .202 & .059 & 3.410 & . ooo & Yes \\
\hline H9 & Core & $\rightarrow$ & NC & .262 & .056 & 4.714 & .000 & Yes \\
\hline H10 & PIS & $\rightarrow$ & NC & .212 & .053 & 3.971 & .000 & Yes \\
\hline H11 & IS & $\rightarrow$ & $\mathrm{NC}$ & 159 & .054 & 2.922 & .003 & Yes \\
\hline H12 & SHPE & $\rightarrow$ & NC & 165 & .055 & 3.005 & .003 & Yes \\
\hline
\end{tabular}

\section{Conclusion and Contribution}

In the present research, the top-level managers' transformational leadership behaviours show significant effects on the middle-mangers' overall organizational commitment. This results also suggests that the transformational leadership behaviours such as core transformational leadership and providing individualized support, intellectual 
stimulation, and setting high performance expectations are crucial variables for building a strong organizational commitment. As indicated by this research results, core transformational leadership has a significant influence on all organizational commitment dimensions (affective, normative, and continuance).. According to Robbins and Judge (2012) affective commitment is driven by an emotional attachment to and identification with the organization. According to Leroy, Palanski, and Simons (2012), social exchange theory serves as the basis for understanding the relationship between transformational leadership and affective commitment. Based on exchange theory, transformational top-level managers engage in positive social exchanges with the middle-level managers. Middle-level managers identify with the top-level managers and the values he/she inspires in the organization. This attachment to the top-level manager results in an increased the level of middle managers' affective commitment. Pillai and Williams (2004) suggest that the collectivistic focus of groups led by transformational leaders may be a stimulation in extracting higher levels of commitment. This is predominantly crucial in middle-level managers led by a transformational top-level manager.

Whereas, transformational leadership behaviors such as, providing individualized support, intellectual stimulation, and setting high performance have impact on both normative and continuance commitment. This indicates that most transformational leadership behaviors emerged as the contributing factor and play important roles in enhancing employee organizational commitment.

Indeed, the result of this research is in line with previous research that found a direct relationship between transformational leadership and affective organizational commitment (Dhawan \& Mulla, 2011; Top, Tarcan, Tekingündüz, \& Hikmet, 2013). The result of this research also partially supports Baek-Kyoo et al. (2012)'s findings that employees showed the highest organizational commitment when their leaders articulated the vision, and promoted group goals. Moreover, the result of this research supports Kim and Kim (2014)'s findings that the transformational leadership measure of intellectual stimulation was not related to employees' affective commitment. The results of this research are also in line with Freeborough (2012)'s findings showing that there is a significant association between transformational leadership and normative commitment. Moreover, the results of this research are in line with research conducted by Tuna et al. (2011) that there is a positive impact between individual consideration and continuance commitment. However, the results of this research contradict O. O. Adebayo (2010)'s findings that affective commitment is not related to any of the dimensions of transformational leadership.

It can be concluded that one of the novel contributions of this research relates to the influence of transformational leadership dimensions on employees' organizational commitment dimensions which have not been adequately and empirically investigated, as is evident in the literature (Meyer et al., 2002; So, 2009). This is particularly so with respect to the non-profit organizations generally (Freeborough, 2012; Porter, 2015), and specifically for Omani public service organizations (S. A. Khan, 2010). This is also one of the objectives of this research. The empirical evidence in support of this objective as initially hypothesised and based on the findings of this study proves there exists a positive and significant impact of some of transformational leadership dimensions on some of organizational commitment dimensions. Moreover, this study contributes to the literature by using a model of transformational leadership that accounts for the influence of the Omani public service employees' organizational commitments. This research empirically investigated the conceptual model and proved that all transformational leadership behaviours such as core transformational leadership and providing individualized support, intellectual stimulating, and setting high performance expectations have a positive and significant influence on normative and continuance organizational commitment. Moreover, the findings of this research demonstrated that the core transformational leadership behaviour is a variable for building middle-managers' affective organizational commitment.

\section{References}

Adebayo, D. (2006). The moderating effect of self-efficacy on job insecurity and organisational commitment among Nigerian public servants. Journal of Psychology in Africa, 16(1), 35-43.

Adebayo, O. O. (2010). Obstetric nurses' perceptions of manager's leadership style on job satisfaction and organizational commitment. UNIVERSITY OF PHOENIX.

AlKindy, A. M., Shah, I. M., \& Jusoh, A. (2016). The Impact of Transformational Leadership Behaviors on Work Performance of Omani Civil Service Agencies. Asian Social Science, 12(3), 152. https://doi.org/10.5539/ass.v12n3p152

Appelbaum, S. H., \& Goransson, L. (1997). Transformational and adaptive learning within the learning organization: a framework for research and application. Learning Organization, The, 4(3), 115-128. https://doi.org/10.1108/09696479710182803 
Aronson, E. (2001). Integrating leadership styles and ethical perspectives. Canadian Journal of Administrative Sciences/Revue Canadienne des Sciences de l'Administration, 18(4), 244-256. https://doi.org/10.1111/j.1936-4490.2001.tb00260.x

Avolio, B. J., Zhu, W., Koh, W., \& Bhatia, P. (2004). Transformational leadership and organizational commitment: Mediating role of psychological empowerment and moderating role of structural distance. Journal of organizational behavior, 25(8), 951-968. https://doi.org/10.1002/job.283

Baek-Kyoo, B. J., Yoon, H. J., \& Jeung, C.-W. (2012). The effects of core self-evaluations and transformational leadership on organizational commitment. Leadership \& Organization Development Journal, 33(6), 564-582. https://doi.org/10.1108/01437731211253028

Bass, B. M. (1985). leadership and performance beyond expectations. New York: The Free Press, 256.

Bass, B. M., \& Avolio, B. J. (1994). Improving organizational effectiveness through transformational leadership. Thousand Oaks, CA: Sage Publications, Inc.

Berberoglu, A., \& Secim, H. (2015). Organizational Commitment and Perceived Organizational Performance Among Health Care Professionals: Empirical Evidence From A Private Hospital in Northern Cyprus. Journal of Economics and Behavioral Studies, 7(1), 64-71.

Bono, J. E., \& Judge, T. A. (2003). Self-concordance at work: Toward understanding the motivational effects of transformational leaders. Academy of Management Journal, 46(5), 554-571. https://doi.org/10.2307/30040649

Burns, J. M. (1978). Leadership. New York: Harper \& Row.

Caldwell, C. (2011). Duties Owed to Organizational Citizens-Ethical Insights for Today's Leader. Journal of business ethics, 102(3), 343-356. https://doi.org/10.1007/s10551-011-0819-8

Common, R. K. (2011). Barriers to developing leadership in the sultanate of Oman. International Journal of Leadership Studies, 6(2), 215-228.

Dhawan, V., \& Mulla, Z. R. (2011). The role of pay and leadership in developing organizational commitment. South Asian Journal of Management, 18(2), 60-75.

Dimaculangan, E. D., \& Aguiling, H. M. (2012). The Effects of Transformational Leadership on Salesperson's Turnover Intention. International Journal of Business and Social Science, 3(19).

Dirani, K. M. (2009). Measuring the learning organization culture, organizational commitment and job satisfaction in the Lebanese banking sector. Human Resource Development International, 12(2), 189-208. https://doi.org/10.1080/13678860902764118

Dunn, M. W., Dastoor, B., \& Sims, R. L. (2012). Transformational Leadership and Organizational Commitment: A Cross-Cultural Perspective. Journal of Multidisciplinary Research, 4(1), 45-60.

Einstein, W. O., \& Humphreys, J. H. (2001). Transforming leadership: Matching diagnostics to leader behaviors. $\begin{array}{lllll}\text { Journal of Leadership \& } & \text { Organizational Studies, } & 8(1), & \text { 48-60. }\end{array}$ https://doi.org/10.1177/107179190100800104

Felfe, J., Tartler, K., \& Liepmann, D. (2004: p.266). Advanced research in the field of transformational leadership. German Journal of Research in Human Resource Management, 18(3), 262-288.

Freeborough, R. E. (2012). Exploring the affect of transformational leadership on nonprofit leader engagement and commitment. (3498733 Ph.D.), Capella University, Ann Arbor. Retrieved from https://vpn.utm.my/docview/928140246?accountid=41678 ProQuest Central; ProQuest Dissertations \& Theses Global database.

Hair, J. J. F., Black, W. C., Babin, B. J., \& Anderson, R. E. (2010). Multivariate data analysis: A global perspective. Upper Saddle River, New Jersey: Pearson Education.

Hajee, Z. R., \& Al Hashemi, S. E. (2012). Leadership Styles: A Study of Managers in Bahraini Organizations. International Journal of Science and Engineering Investigations, 1(7), 36-46.

Hooper, D., Coughlan, J., \& Mullen, M. (2008). Structural equation modelling: Guidelines for determining model fit. Journal of Business Research Methods, 6, 53-60.

Hunter, L. W., \& Thatcher, S. M. (2007). Feeling the heat: Effects of stress, commitment, and job experience on job performance. Academy of Management Journal, 50(4), 953-968. https://doi.org/10.5465/AMJ.2007.26279227 
Jafri, M. H., \& Lhamo, T. (2013). Organizational Commitment and Work Performance in Regular and Contract Faculties of Royal University of Bhutan. Journal of Contemporary Research in Management, 8(2), 47-58.

Karim, N. H. A., \& Noor, N. (2006). Evaluating the psychometric properties of Allen and Meyer's organizational commitment scale: a cross cultural application among Malaysian academic librarians. Malaysian Journal of Library and Information Science, 11(1), 89.

Khan, S. A. (2010). Managing Performance: The Case of an Omani Oil Company. Vision: The Journal of Business Perspective, 14(4), 285-293. https://doi.org/10.1177/097226291001400405

Khan, Z., Khan, S., \& Shahzad, S. (2013). Moderating Role of Procedural Justice and Empowerment in Transformational Leadership with its impact on Organizational Commitment. International Review of Management and Business Research, 2(3), 847-852.

Kim, S. G., \& Kim, J. (2014). Integration Strategy, Transformational Leadership and Organozational Commitment in Korea's Coorporate Split-offs. Procedia-Social and Behavioral Sciences, 109, 1353-1364. https://doi.org/10.1016/j.sbspro.2013.12.637

Kuchinke, K. P. (1999). Leadership and culture: Work - related values and leadership styles among one company's US and German telecommunication employees. Human Resource Development Quarterly, 10(2), 135-154. https://doi.org/10.1002/hrdq.3920100205

Leroy, H., Palanski, M. E., \& Simons, T. (2012). Authentic leadership and behavioral integrity as drivers of follower commitment and performance. Journal of Business Ethics, 107(3), 255-264. https://doi.org/10.1007/s10551-011-1036-1

Mancini, B. A. (2008). The relationship of transformational and transactional leadership to job satisfaction and organizational commitment within for-profit organizations on Long Island, New York. (3312894 Ed.D.), Dowling College, Ann Arbor. Retrieved from https://vpn.utm.my/docview/304820272?accountid=41678 ProQuest Central; ProQuest Dissertations \& Theses Global database.

Marique, G., Stinglhamber, F., Desmette, D., Caesens, G., \& De Zanet, F. (2012). The relationship between perceived organizational support and affective commitment: A social identity perspective. Group \& Organization Management, 1059601112457200.

Mathieu, J. E., \& Zajac, D. M. (1990). A review and meta-analysis of the antecedents, correlates, and consequences of organizational commitment. Psychological bulletin, 108(2), 171-194. https://doi.org/10.1037/0033-2909.108.2.171

Meyer, J. P., \& Allen, N. J. (1991). A three-component conceptualization of organizational commitment. Human resource management review, 1(1), 61-89. https://doi.org/10.1016/1053-4822(91)90011-Z

Meyer, J. P., \& Allen, N. J. (1997). Commitment in the workplace: Theory, research, and application: Thousand Oaks: Sage.

Meyer, J. P., Allen, N. J., \& Smith, C. A. (1993). Commitment to organizations and occupations: Extension and test of a three-component conceptualization. Journal of Applied Psychology, 78(4), 538-551. https://doi.org/10.1037/0021-9010.78.4.538

Meyer, J. P., Stanley, D. J., Herscovitch, L., \& Topolnytsky, L. (2002). Affective, continuance, and normative commitment to the organization: A meta-analysis of antecedents, correlates, and consequences. Journal of vocational behavior, 61(1), 20-52. https://doi.org/10.1006/jvbe.2001.1842

Ministry of Civil Service. (2012). Retrieved from http://www.mocs.gov.om/tabid/533/Default.aspx , 13.9.2012.

Morrow, P. C. (2011). Managing organizational commitment: Insights from longitudinal research. Journal of vocational behavior, 79(1), 18-35. https://doi.org/10.1016/j.jvb.2010.12.008

Mowday, R. T., Steers, R. M., \& Porter, L. W. (1979). The measurement of organizational commitment. Journal of vocational behavior, 14(2), 224-247. https://doi.org/10.1016/0001-8791(79)90072-1

Northouse, P. G. (2010). Leadership: Theory and practice (5th ed.): Sage Publications.

Northouse, P. G. (2012). Leadership: Theory and practice (6th ed.): Sage Publications.

Nusair, N., Ababneh, R., \& Bae, Y. K. (2012). The impact of transformational leadership style on innovation as perceived by public employees in Jordan. International Journal of Commerce and Management, 22(3), 182-201. https://doi.org/10.1108/10569211211260283 
Piccolo, R. F., \& Colquitt, J. A. (2006). Transformational leadership and job behaviors: The mediating role of core job characteristics. Academy of Management Journal, 49(2), 327-340. https://doi.org/10.5465/AMJ.2006.20786079

Pieterse, A. N., Van Knippenberg, D., Schippers, M., \& Stam, D. (2010). Transformational and transactional leadership and innovative behavior: The moderating role of psychological empowerment. Journal of organizational behavior, 31(4), 609-623. https://doi.org/10.1002/job.650

Pillai, R., \& Williams, E. A. (2004). Transformational leadership, self-efficacy, group cohesiveness, commitment, and performance. Journal of organizational change management, 17(2), 144-159. https://doi.org/10.1108/09534810410530584

Podsakoff, P. M., MacKenzie, S. B., \& Bommer, W. H. (1996). Transformational leader behaviors and substitutes for leadership as determinants of employee satisfaction, commitment, trust, and organizational $\begin{array}{llll}\text { citizenship behaviors. Journal of } & \text { 259-298. }\end{array}$ https://doi.org/10.1177/014920639602200204

Podsakoff, P. M., MacKenzie, S. B., Moorman, R. H., \& Fetter, R. (1990). Transformational leader behaviors and their effects on followers' trust in leader, satisfaction, and organizational citizenship behaviors. The Leadership Quarterly, 1(2), 107-142. https://doi.org/10.1016/1048-9843(90)90009-7

Porter, J. A. (2015). The relationship between transformational leadership and organizational commitment in nonprofit long term care organizations: The direct care worker perspective. Creighton Journal of Interdisciplinary Leadership, 1(2), 68-85. https://doi.org/10.17062/cjil.v1i2.13

Randeree, K., \& Chaudhry, A. G. (2012). Leadership - style, satisfaction and commitment. Engineering, Construction and Architectural Management, 19(1), 61-85. http://dx.doi.org/10.1108/09699981211192571

Robbins, S. P., \& Judge, T. A. (2012). Essentials of organizational behavior (11th ed.). Upper Saddle River, NJ: Prentice Hall.

Sarros, J. C., Gray, J. H., \& Densten, I. L. (2002). Leadership and its impact on organizational culture. Journal of International Business Studies, 10(2), 1-26.

Schriesheim, C. A., Alonso, S., \& Neider, L. L. (2008). A quantitative examination of the content validity and theoretically dimensionality of the Transformational Leadership Inventory (TLI), Paper presented in the Research Methods Track. Southern Management Association Annual Meeting, St. Petersburg Beach, Fl, October 29-November 21.

Shamir, B., House, R. J., \& Arthur, M. B. (1993). The motivational effects of charismatic leadership: A self-concept based theory. Organization science, 4(4), 577-594. https://doi.org/10.1287/orsc.4.4.577

Shaw, J. D., Delery, J. E., \& Abdulla, M. H. (2003). Organizational commitment and performance among guest workers and citizens of an Arab country. Journal of Business Research, 56(12), 1021-1030. https://doi.org/10.1016/S0148-2963(01)00316-2

Shurbagi, A. M. A. (2014). The Relationship between Transformational Leadership Style Job Satisfaction and the Effect of Organizational Commitment. International Business Research, 7(11), 126. https://doi.org/10.5539/ibr.v7n11p126

So, E. (2009). The effects of leadership on organizational commitment in China: The moderating role of collectivism. (MR56781 M.A.), University of Guelph (Canada), Ann Arbor. Retrieved from https://vpn.utm.my/docview/304890150?accountid=41678 ProQuest Dissertations \& Theses Global database.

Srivastava, M. K. (2003). Transformational leadership: New Delhi: Macmillan India Ltd.

Top, M., Tarcan, M., Tekingündüz, S., \& Hikmet, N. (2013). An analysis of relationships among transformational leadership, job satisfaction, organizational commitment and organizational trust in two Turkish hospitals. The International journal of health planning and management, 28(3), 217-241. https://doi.org/10.1002/hpm.2154

Tuna, M., Ghazzawi, I., Akbas Tuna, A., \& Catir, O. (2011). Transformational Leadership and Organizational Commitment: The Case of Turkey's Hospitality Industry. SAM Advanced Management Journal, 76(3), 10-27.

Walumbwa, F. O., \& Lawler, J. J. (2003). Building effective organizations: transformational leadership, collectivist orientation, work-related attitudes and withdrawal behaviours in three emerging economies. 
International journal of human resource management, 14(7), 1083-1101. https://doi.org/10.1080/0958519032000114219

Wang, X., Ma, L., \& Zhang, M. (2014). Transformational leadership and agency workers' organizational commitment: The mediating effect of organizational justice and job characteristics. Social Behavior and Personality: an international journal, 42(1), 25-36. https://doi.org/10.2224/sbp.2014.42.1.25

Yang, M.-L. (2012). Transformational leadership and Taiwanese public relations practitioners' job satisfaction and organizational commitment. Social Behavior and Personality: an international journal, 40(1), 31-46. https://doi.org/10.2224/sbp.2012.40.1.31

Yousef, D. A. (1998). Correlates of perceived leadership style in a culturally mixed environment. Leadership \& Organization Development Journal, 19(5), 275-284. https://doi.org/10.1108/01437739810234341

Yousef, D. A. (2000). Organizational commitment: A mediator of the relationships of leadership behavior with job satisfaction and performance in a non-western country. Journal of Managerial Psychology, 15(1), 6-24. https://doi.org/10.1108/02683940010305270

Yukl, G. A. (1998). Leadership in organizations (4th ed.): Englewood Cliffs, NJ: Prentice-Hall.

Zhu, W., Avolio, B. J., \& Walumbwa, F. O. (2009). Moderating role of follower characteristics with transformational leadership and follower work engagement. Group \& Organization Management, 34, 590-619. https://doi.org/10.1177/1059601108331242

\section{Copyrights}

Copyright for this article is retained by the author(s), with first publication rights granted to the journal.

This is an open-access article distributed under the terms and conditions of the Creative Commons Attribution license (http://creativecommons.org/licenses/by/4.0/). 